\title{
Theoretical assumptions of Maffesoli's sensitivity and Problem-Based Learning in Nursing Education ${ }^{1}$
}

\author{
María-Aurora Rodríguez-Borrego ${ }^{2}$ \\ Rosane Gonçalves Nitschke ${ }^{3}$ \\ Marta Lenise do Prado 4 \\ Jussara Gue Martini ${ }^{3}$ \\ María-Dolores Guerra-Martín ${ }^{5}$ \\ Carmen González-Galán ${ }^{6}$
}

Objective: understand the everyday and the imaginary of Nursing students in their knowledge socialization process through the Problem-Based Learning ( $\mathrm{PBL}$ ) strategy. Method: Action Research, involving 86 students from the second year of an undergraduate Nursing program in Spain. A Critical Incident Questionnaire and Group interview were used. Thematic/categorical analysis, triangulation of researchers, subjects and techniques. Results: the students signal the need to have a view from within, reinforcing the criticism against the schematic dualism; PBL allows one to learn how to be with the other, with his mechanical and organic solidarity; the feeling together, with its emphasis on learning to work in group and wanting to be close to the person taking care. Conclusions: The great contradictions the protagonists of the process, that is, the students experience seem to express that group learning is not a form of gaining knowledge, as it makes them lose time to study. The daily, the execution time and the imaginary of how learning should be do not seem to have an intersection point in the use of Problem-Based Learning. The importance of focusing on the daily and the imaginary should be reinforced when we consider nursing education.

Descriptors: Problem Based Learning; Education, Nursing; Students, Nursing.

\footnotetext{
${ }^{1}$ Supported by Universidad de Córdoba.

${ }^{2}$ PhD, Full Professor, IMIBIC, Hospital Universitario Reina Sofía, Universidad de Córdoba, Córdoba, Spain.

${ }^{3} \mathrm{PhD}$, Adjunct Professor, Departamento de Enfermagem, Centro de Ciências da Saúde, Universidade Federal de Santa Catarina, Florianópolis, SC, Brazil.

${ }^{4}$ PhD, Associate Professor, Departamento de Enfermagem, Centro de Ciências da Saúde, Universidade Federal de Santa Catarina, Florianópolis, $\mathrm{SC}$, Brazil.

${ }^{5} \mathrm{PhD}$, Full Professor, Facultad de Enfermería, Universidad de Sevilla, Sevilla, Spain.

${ }^{6} \mathrm{RN}$.
}

\section{Corresponding Author:}

María-Aurora Rodríguez-Borrego

Universidad de Córdoba. Departamento de Enfermería

Edifício Servicios Múltiples

Avda. Menéndez Pidal s/n

14004, Córdoba, España

E-mail: en1robom@uco.es
Copyright (c) 2014 Revista Latino-Americana de Enfermagem This is an Open Access article distributed under the terms of the Creative Commons Attribution Non-Commercial License (CC BY-NC).

This license lets others distribute, remix, tweak, and build upon your work non-commercially, and although their new works must also acknowledge you and be non-commercial, they don't have to license their derivative works on the same terms. 


\section{Introduction}

The subject Basic Nursing Care [6 ECTS (European Credit Transfer System)] is offered in the second year of the recently created undergraduate degree program in Nursing (CA 2009/2010); this subject started in the academic year 2010/2011. The novelty relates to its name $^{(1)}$, not its reference framework; in the framework of the knowledge area Nursing Fundamentals, the subjects' program contents provide the students with a global view of Nursing practice and with the concepts and methods needed to understand and advance in the subject. In the curriculum, the function of these contents is to center, support, frame and structure(2). The current reality of the new degree programs seems to drive the transformation of the teaching models in place; nevertheless, in the Nursing profession, whose function is the establishment of a help relation with the "other", "Taking Care of the Other", these innovations are demanded by the citizens' care needs. The general objectives of the subject include the identification of the patient/client... human being's individual needs, deriving from the basic parameters of man as a bio-psycho-social and ecological being, as well as from their skills to cope with the situations; thus, in terms of competences, the goal is to enable the students to apply the Nursing Process in order to provide and guarantee the attended people's wellbeing, quality and safety. Coping with these challenges finds a parallel in many of the aspects covered in the European convergence process ${ }^{(3)}$, such as: quality guarantees, autonomy with responsibility, articulation of diversity, adaptation of teaching to the needs of the job market, learning across the lifetime, the development of fundamental values or the consideration of universities as a public responsibility.

This broad perspective of desires and needs, from the viewpoint of the teaching-learning process, seems to lead to cooperative methods. Collaborative learning $(\mathrm{CL})$ is a form of group work based on the collective construction of knowledge and the development of mixed skills (learning and personal and social development), in which each group member is responsible for his own and the other group members' learning, and which has showed to be particularly useful in the development of generic and cross-sectional competences - the ability to adapt to new situations, generate new ideas, apply the knowledge to practice ${ }^{(4)}$. Five components are identified: positive interdependence, constructive faceto-face interaction, individual and group responsibility, verbal and non-verbal interpersonal communication techniques and metacognitive control of the group ${ }^{(5)}$. The same methodological strategy of cooperation includes Problem-Based Learning ( $\mathrm{PBL}$ ), an instrument that facilitates the acquisition of the abovementioned generic, but also of specific competences, as it permits the simultaneous development of problem-solving strategies and of the knowledge bases and specific skills of a concrete discipline ${ }^{(6)}$, using cooperation as a problem-solving instrument.

The cooperative methods in general and CA and PBL in particular have demonstrated their effectiveness in all kinds of educative environments, and can be applied independently of the particular subject that is to be taught ${ }^{(7-8)}$. In their implementation, the common element is that, in these strategies, the students serve as the protagonists of their learning(9). In the subject taught, the Problem-Based Learning strategy was used with the general objective of achieving significant learning about what the Nursing Care Process implies for the people receiving the care. Ausubel(10) and his significant learning theory indicates that this learning is acquired when the students relates the new with the previously gained knowledge, although they need to take interest in learning what is being shown. This whole theoretical and methodological framework talks about constructivism, where "The place made link" according to Maffesoli(11), and where the daily reality of the human experience process and the sensitive reasons that constitute it gain particular relevance. "When nothing is important, everything becomes important. And the small phenomena of current life, the uses and customs without attributes, the trivial rituals that determine the individual or collective existence, all of this constitutes the humus in which the post-modern being together is developed". Mafessoli(12) invites us to "live up to the everyday", considering the everyday as "the human beings" way of life that is shown in the daily life, through their interactions, beliefs, values, meanings, culture, symbols, which outline their life process, in a movement of being healthy and ill, directing their life cycle. We need spaces in which we can stop and discuss our process of living and educating"(13). And it was the daily reality of the second-year students from the Nursing program, in their experience of the methodological change, of the knowledge socialization, of their imaginary in view of and about the profession they selected - determinants of their learning - that served as the focus of interest for the proposed research and methodological innovation. It is highlighted that the imaginary is this entire world of meanings, ideas, fantasies, the evocation of already 
perceived or unperceived figures, beliefs, values... which the human being is submersed in ${ }^{(14)}$.

It were the experiences of the Nursing students, their interpretations, their meanings, the sensitive reason of each that marked the agenda of change. Thus, submersed in Maffesoli's theoretical assumptions and sensitivity, discussed in Nursing by Nitschke(15), and which are: dualism (reason and imagination); form (context, situations and representations that constitute daily life); relativist sensitivity (the understanding of the complex and plural); stylistic investigation (coherence of time and discourse, feedback theory and practice) and liberating thinking (feeling the subtleties, the nuances, the discontinuities; see through the "eyes of the other"); these turned into the observation points in the search for answers to our questions: How do the students experience the socialization process and Problem-Based Learning? What are the meanings they attribute to it?

\section{Objective}

Get to know the everyday life and the imaginary of the Nursing students in their knowledge socialization process by means of Problem-Based Learning (PBL), through the perspective of the theoretical assumptions of sensitivity.

\section{Methods}

The selected Design was a participatory Action Research with a qualitative analysis strategy. The study was undertaken at a Nursing College of a University in Southern Spain. It was developed between April 2010 and September 2011. The participants were students from the second class of the Undergraduate Nursing program, including two groups of 60 students each who were enrolled for the subject Basic Nursing Care. The subjects were characterized based on the following data: Age; Gender; Access to education. The analytic categories were: the everyday and Maffesoli's theoretical assumptions and sensitivity (dualism, form, relativist sensitivity, stylistic investigation, liberating thinking) and collaborative learning (positive interdependence; constructive face-to-face interaction; individual and group responsibility; verbal and nonverbal interpersonal communication techniques; metacognitive control of the group). The following data collection instruments were used: Critical Incident Questionnaire (CIQ): statement of positive and negative aspects about the experience; three across the research period, on the following dates: November $12^{\text {th }}$, December $17^{\text {th }}$ and April $5^{\text {th }}$ for Group I; November $12^{\text {th }}$, December $17^{\text {th }}$ and April $4^{\text {th }}$ for Group II; the application of the questionnaire took three minutes. The Group interview took place on April $5^{\text {th }}$ with Group I and April $4^{\text {th }}$ with Group II. The first CIQ was administered before the start of the process and the second during the development of the case; the third CIQ and the group interview were held two months after concluding the case and the four-month period, after the evaluation and after the grades for the subject had been distributed; Group I had terminated its clinical training and Group II was starting its training period. The group interview was held in the classroom, in each of the large groups, and the students' participation was on a voluntary base. An external collaborator administered the interview, using open questions, and the answers were collected and categorized using the same method as the CIQs. The Intervention studied was the development of the program contents in the subject Basic Nursing Care with the help of the ProblemBased Learning strategy; Introduction of actions: three group tutoring sessions per large group: November $26^{\text {th }}$, December $10^{\text {th }}$ and January $14^{\text {th }}$; the sessions were held on the same day for both groups but on different times; doubts were addressed, solutions were envisaged for the problems raised in the monitoring of the case and in the evolution of the collaborative groups; and new lines of work were started. Thematic/ categorical analysis was applied(16-17). The triangulation involved researchers [primary researcher (course lecturer); external observer (teacher who applied the third CIQ and group interviews); external observer (teachers who developed the content analyses); subjects (students) and techniques (CIQs and group interviews). The ethical aspects included the students' verbal and written consent and the protocol approved by the Bioethics Committee of the Universidad de Córdoba (Registration number 714). The study is limited by the fact that the third CIQ and the group interviews were not held on the same day, which did not happen with the other two CIQs; this may cause some mutual influence among the students' answers. On the day of the third CIQ and the group interview, Group I had finished the practicum and Group II had not. This situation creates some inequality when comparing the categories of the everyday and Maffesoli's theoretical assumptions and sensitivity in both groups, in view of the distinct and disparate perspectives and expectations regarding aspects of the clinical reality. 


\section{Results}

\section{Sociodemographic profile}

In total, 114 students were enrolled; 58 in Group I and 56 in Group II. Group I included 49 women and nine men. Group II consisted of 42 women and 14 men. However, the following completed the CIQs: Group I: $1^{\text {st }}$ CIQ (November $\left.12^{\text {th }}\right) 43$ students, $2^{\text {nd }}$ CIQ (December $17^{\text {th }}$ ) 40 and $3^{\text {rd }}$ CIQ (April $5^{\text {th }}$ ) 16 . Group II: $1^{\text {st }}$ CIQ (November $12^{\text {th }}$ ) 43 students, $2^{\text {nd }}$ CIQ (December $17^{\text {th }}$ ) 30 and $3^{\text {rd }}$ CIQ (April $4^{\text {th }}$ ) 30. In the group interview, 16 students from Group I and 30 from Group II participated. Data on the students' gender and age were only collected in the third CIQ, after the evaluation of the subject. In the first, the intent was to avoid the students' fear of being identified. The mean age was 22.5 (19-45) years in Group I and 20.4 (19-34) in Group II. As regards gender, Group I included 13 women and Group II 23; there were three men in Group I and seven in Group II.

Concerning their studies before starting college, in Group I, eight people had taken a Bachelor program, seven degree programs and one had access through the program for people over 25 years of age. In Group II, 13 people came from Bachelor programs and 17 either did not know or could not answer. The experience with PBL (before starting college) was collected as another significant variable. In Group I, 15 people did not have preliminary experience with PBL and one person did not know/could not answer. In Group II, 30 people did not have preliminary experience with $\mathrm{PBL}$; it should be reminded that these data were collected in the third CIQ, when less students participated than in the first two.

The students' experiences were categorized based on the categories of the everyday and Maffesoli's theoretical assumptions and sensitivity, as well as on collaborative learning, in which no substantial differences were observed with regard to the filiation variables; the most significant data are highlighted in the Discussion, shown next.

\section{Discussion}

The assumption criticism against the schematic dualism is perceptible in PBL. Maffesoli signals that any thought involves two complementary attitudes, which are difficult to define exactly, as they reflect different potentials, such as reason and imagination. The author highlights that, on the one hand, the emphasis is on construction, criticism, mechanism, reason; and, on the other, on nature, feeling, the organic and imagination. While some intellectuals work with abstraction, others look for empathy. There is always a direction towards the dichotomy ${ }^{(18)}$. The students indicate well this need for a view from within: in the direct contact with people, Not being able to see the case for real and being obliged to imagine many situations. Therefore, Maffesoli(11) proposes a science from within, in which the thinker, that is "the person who thinks the world", does not have to withdraw, as he is part of what he describes, he is in the interior, and can thus have a view from within, an intuition. $\mathrm{PBL}$, in turn, permits learning to be with the other; with its mechanical and organic solidarity, It helps to understand the subject, Helps to develop the reasoning, Helps to improve the group dynamics. An ethics of esthetics, empathy also emerges when they signal: Cooperation in a group, as a form of interacting with the patient. The feeling together, with its emphasis on learning to work in a group, We learn to work in a group and the desire to be close to the person who cares. At the same time, PBL permits reasoning, objectivity, and is crossed by the "logic of the need to be" while describing a mechanical solidary "an established being together", It obliges us to investigate many distinct themes.

The Prometheus myth accompanies the process, showing an Apollonian walk(19) surrounded by rules, projected into the future: As a positive element we get learning, the awareness one needs when working, what rules to follow when doing a job, We learn to cope with problems we may be confronted with in the future.

The integration between practice and theory also expresses this assumption of the criticism against the schematic dualism: The theory needs to be put in practice. The contribution to a perspective on people as holistic, multidimensional and complex beings equally shows this criticism against the schematic dualism: It allows us to get a comprehensive view on the person. These aspects also lead to the assumption: a relativist sensitivity. According to Maffesoli, there is not just one single reality ${ }^{(17)}$. This entire heterogeneous and plural world demands a systematic understanding with the broadest possible spectrum, showing a science that integrates "specialized knowledge into a plural knowledge that is always being developed and broken down"(13). The systematic reflection that tries to describe the interaction that vitalizes it into a complex order is attentive to the paradoxical and heterogeneous sides of living as presented in the emphasis on group work. This receives a whole range of theatricality, involving the 
use of masks, double game, duplicity, when the group work shows the masks of the coordinator (leader) as well as the person hiding and being hidden in the group work. It should be reminded that the mask does not mean falsehood, but a possibility of protection. This also reveals the duplicity in the expressions themselves: positive-negative, or when considering on the one hand $\mathrm{PBL}$ as a way to integrate theory and practice, at the same time as they express that the strategy does not serve for this integration because it works with idealized cases, PBL is very theoretical and does not have anything to do with the care practice at the hospital, I though that, in PBL they put up a real-life case in order to be able to learn to confront these cases, The $P B L$ case raises many doubts but one cannot ask the patients as it is an unreal case. Thus, the unreal, the real and the ideal, being paradoxical, are relativized; the same is true for time, as PBL demands a lot of time, but can also need little; or going beyond and being a waste of time for some. PBL is a waste of time, as you lose a lot of time to study; The PBL study takes about 100 pages and we have to present it in 10 minutes and that's not enough time, They should include more hours for the evaluation, Little time is dedicated to the evaluation... The assumption of liberating thinking can also be evidenced: We value the groups' ideas and their forms of thinking, Maffesoli defends that "it is more fruitful to act in order to liberate the perspective"(14), reminding us of his similarity with Paulo Freire's thinking(20-22). Based on Balandier and Tourraine, who talk about the interaction among different thoughts that, by breaking down the "baronies of knowledge" and the "carefully guarded thematic circumscriptions", turn the innovators into a disturbing spur to the established, Maffesoli(14) mentions that the expert needs to "know how to be born innocently each morning. Forgetting is a strength that permits a new look." Liberating thinking rests on the notion of typical behavior. Thus, Maffesoli talks about the investigator, the teacher and the student as actors and participants, clarifying that this is not a generalized requirement but that certain methods demand it, including the establishment of an interaction between the observer and his study object. Thus, the students demand proximity with the patient, There is no communication with the patient and you have to imagine a lot of data, We always stick to planning in PBL, If it were a real case it would be easier as we could ask the patient, once again underlying the ethics of esthetics. In this context, there is complicity, joint life, empathy. That is when Maffesoli shares a notion of comprehension, which supports this research. According to him(14), "understanding implies a generous spirit, proximity, correspondence", which permits "apprehending or feeling the subtleties, the nuances, the discontinuities" of any social situation; this needs an attitude of empathy. In other words, one might say that understanding means exercising the "seeing through the other person's eyes", recovering one's own look that will already be "imbued" with the other person's look ${ }^{(15)}$. PBL transforms an image, contributes to move from an image of teaching and learning to another, provoking the established culture and questioning a cultural determinism of teaching and learning. "It's a culture shock!!! A sequential and constant transfiguration of images!", as he provokes us ${ }^{(13)}$. In his fourth assumption: a stylistic investigation, Maffesoli alerts that science needs to express itself in the way of "knowing to speak at the right time". Thus, in our opinion, there is a proposal that contributes to reduce the gap between the academy and the community in general, something that has been defended for a long time. He proposes that science should disclose itself through a constant feedback between empathy and the polyphonic form, that it should simultaneously reflect on itself and, without losing its scientific rigor, be of interest to the social protagonists, "We start to know what we have to say... but we haven't found the way to say it yet"(14). It is based on this proposal that Maffesoli presents an analogy and a metaphor as essential elements of what he calls procedure, demanding a way to express the polysemy of the sounds, gestures and situation that compose the "social plot". Besides integrating this assumption, Maffesoli calls attention to the aspect of leaving a problem open, as it arouses debate and other perspectives and may even be contradictory, revealing the whole diversity that throbs in life and joint life. As he alerts, however: "It is, finally, quite evident that - knowing how to say - is not synonymous with saying everything. There are imprecisions that are at the same time delicacies in view of the complexity of things, and respect for the reader. Pirouettes that are not abdications of the spirit at all, but invitations for a deeper understanding... This open procedure naturally is hardly satisfactory to everyone who is in need of certainties"(14). A permanent mutual relation exists among these assumptions, show intrinsic and extrinsic interactions show a relief. According to Maffesoli, knowledge can be "based on the person's private interests and interactions"(14). 


\section{Conclusions}

The existing literature about teaching methods verifies the importance of Problem-Based Learning in a wide range of knowledge areas, and especially in the Health Sciences. This project provides support. We believe we have achieved the proposed objective, although the novelty of the teaching experience was to get to the bottom of the meaning the students attribute to the methodological changes, and this circumstance has evidenced the great contradictions the protagonists of the process, that is, the students, experience. The daily reality, the execution time and the imaginary of how learning needs to be do not seem to have an intersection point in the use of Problem-Based Learning. The socializing aspect of the collaborative learning strategy is also questioned, in turn, as the students seem to express that group learning is not a form of gaining knowing, by reducing their time to study.

In the framework of the challenge the European Higher Education Area poses, in which the methodological change reveals to be an unquestionable condition, the above arouses questions as to whether the methodological change is a need the teachers or the students feel, or if both share common interests. Furthermore, and given the circumstances, the question could be raised whether the objective is for the students to gain specific knowledge on a subject or to learn to live and work with their peers and reach agreements. On the other hand, it should also be questioned whether the students assumed that the work hours beyond the classroom count, or whether they know what an ECTS (European Credit Transfer System) credit is, or whether they have indepth knowledge about its meaning. Anyway, the process has supposed the perturbation of established certainties, which makes the researchers in this project reflect on the implications of their results for practice. When we consider education in daily life, we know that the word may mean a lot, but that attitudes and interactions express much more. Our practice has driven us to reinforce the importance of focusing on the everyday if one wants to promote life, healthy beings and families.

\section{References}

1. BOE. Resolución de 23 de marzo de 2010, por la que se publica el plan de estudios de Graduado en enfermería. no 88, 12 abril 2010.
2. Rodríguez Borrego MA. Guía docente de Cuidados Básicos de Enfermería de Graduado en Enfermería: Curso Académico 2010/2011. Córdoba: Universidad de Córdoba (ES); 2010.

3. Rodríguez-Borrego MA, Boronat-Mundina J. La responsabilidad, fundamento de la educación democrática y colaborativa en la enseñanza universitaria: Estudio de casos en el área de Enfermería. The Collaborative Action Research Network. 2008;13:13-21.

4. Johnson DW, Johnson R. Cooperation and Competitions. Theory and Research. Edina, MN: Interaction Book; 1989 5. Johnson D, Johnson R. El aprendizaje cooperativo en el aula. Barcelona: Ed. Paidos; 1999.

6. Escriban A, Del Valle A. Coordinadoras. El aprendizaje Basado en Problemas. Una propuesta metodológica en Educación Superior. Madrid: Ed. Nancea; 2008.

7. Prado ML do, Schubet Backes VM, Brüggemann OM. Democratização de produção do conhecimento e acessibilidade à informação: desafios para a qualificação da prática de Enfermagem. Biblioteca Lascasas. [Internet]. 2008 [acesso 16 out 2012]; 4(1). Disponível em: /lascasas/documentos/lc0308.php

8. Rodríguez Borrego MA. Metodologías colaborativas, educação na e para a responsabilidade na formação em enfermagem. SISIFO. Rev Ciênc Educ. 2008; 7:61-72.

9. Guerra Martín MD. Opiniones de los estudiantes de Enfermería sobre el Aprendizaje Basado en Problemas. Enferm Global. [Internet]. 17. 2009 [acesso 13 jan 2011]; Disponível em: www.um.es/eglobal/

10. Ausubel D. In defense of advance organizers: A reply to the critics. Rev Educ Res. 1978;48:251-7.

11. Maffesoli M. Notas sobre a pós-modernidade. O lugar faz o elo. Rio de Janeiro: Ed. Atlântica; 2004.

12. Maffesoli M. Iconologías. Nuestras idolatri@s posmodernas. Barcelona: Ed. Península; 2009.

13. Nitschke R. Pensando o nosso quotidiano contemporâneo e a promoção de famílias saudáveis. Ciênc Cuidado Saúde. 2007;6(1):24-6.

14. Maffesoli M. O conhecimento do quotidiano: para uma sociologia da compreensão. Lisboa: Ed. Veja; 1997.

15. Nóbrega J, Nitschke R, Souza A, Santos E. A Sociologia compreensiva de Michel Maffesoli: implicações para a pesquisa em enfermagem. Cogitare Enferm. 2012;17:373-6.

16. Gerrish K, Lacey A. Investigación en Enfermería. Madrid: Ed. Mcgraw-Hill/ Interamericana; 2008.

17. Solis Muñoz M. Percepción de la calidad asistencial en mujeres a las que se les ha realizado una mamografía. Metas Enferm. 2009;11(3):14-9. 
18. Maffesoli M. O conhecimento comun. Introduçao

à sociología compreensiva. Porto Alegre: Ed. Meridional; 2010.

19. Maffesoli M. Quem é Michel Maffesoli: entrevistas com Christophe Bourseille. Petrópolis; 2011.

20. Freire P. Pedagogia do oprimido. São Paulo: Ed. Paz e Terra; 1987.

21. Freire P. Pedagogia da esperança. Um reencontro com a pedagogia do oprimido. Rio de Janeiro: Ed. Paz e Terra; 1997.

22. Freire P. Pedagogia da autonomia. Saberes necessários à prática educativa. São Paulo: Ed. Paz e Terra; 1997. 